\title{
Glutamate Receptor-interacting Protein 1 Protein Binds to the Armadillo Family Protein p0071/plakophilin-4 in Brain
}

\author{
II Soo Moon ${ }^{1}$ and Dae-Hyun Seog* \\ Departments of Biochemistry, College of Medicine, Inje University, Busan 614735, Korea \\ ${ }^{1}$ Departments of Anatomy, College of Medicine, Dongguk University, Gyeongiu, Korea
}

Received June 1, 2009 / Accepted June 10, 2009

\begin{abstract}
$\alpha$-amino-3-hydroxy-5-methyl-4-isoxazole propionate (AMPA) receptors are widespread throughout the central nervous system and appear to serve as synaptic receptors for fast excitatory synaptic transmission mediated by glutamate. Their modulation is believed to affect learning and memory. To identify the interaction proteins for the AMPA receptor subunit glutamate receptor-interacting protein 1 (GRIP1), GRIP1 interactions with armadillo family protein p0071/plakophilin-4 were investigated. GRIP1 protein bound to the tail region of p0071/plakophilin-4 but not to other armadillo family protein members in a yeast two-hybrid assay. The "S- $\mathrm{X}-\mathrm{V}^{\text {" }}$ motif at the carboxyl (C)-terminal end of p0071/plakophilin-4 is essential for interaction with GRIP1. p0071/plakophilin-4 interacted with the Postsynaptic density-95/Discs large/Zona occludens-1 (PDZ) domains of GRIP1 in the yeast two-hybrid assay, as is indicated also by Glutathione $S$-transferase (GST) pull-down, and co-immunoprecipitated with GRIP1 antibody in brain fraction. The findings of this study provide evidence that p0071/plakophilin-4 is an interactor of GRIP1.
\end{abstract}

Key words : $\alpha$-amino-3-hydroxy-5-methyl-4-isoxazole propionate (AMPA) receptor, armadillo family, glutamate receptor-interacting protein 1 (GRIP1), binding protein

\section{Introduction}

Most excitatory synapses in brain use glutamate as an excitatory neurotransmitter. Three classes of glutamate receptors mediate its action. AMPA, kainite and N-methyl-D-asparatate (NMDA) receptors bind glutamate released from the presynaptic nerve terminal and produce a depolarization of the postsynaptic membrane $[7,10,16,19]$. AMPA receptor channels comprise heterotetramers of subunits GluR1-4 [16]. Each subunit has a large N-terminal extracellular domain, three transmembrane domains and a C-terminal intracellular domain. The C-termini of these receptor subunits interact with several intracellular PDZ domain-containing proteins $[9,19]$. Some PDZ domain-containing proteins act as adaptor/scaffolding proteins that target, anchor, and spatially organize synaptic protein to the membrane $[27,29]$. This regulation of the interaction of GluR2 with PDZ-domain containing proteins could be important in regulation of the synaptic targeting and localization of AMPA receptors [28]. PDZ domains have a molecular structure of 80-100 amino acids and are found in many cytoplas-

*Corresponding author

Tel : +82-51-890-6974, Fax : +82-51-894-5801

E-mail : daehyun@inje.ac.kr mic proteins, usually in conjunction with other interaction domains [3,17].

Glutamate receptor-interacting protein 1 (GRIP1) contains seven PDZ domains and binds to the C-terminus of the GluR2 and GluR3 subunits of AMPA receptors. Disruption of the GRIP1 PDZ-GluR2 interaction prevents AMPA receptor recruitment to the synapse $[9,21,25,30]$, suggesting that it serves as a scaffolding protein to link AMPA receptors to other neuronal proteins. It has been reported that GRIP1 binds to Kinesin superfamily protein 5 (KIF5; the molecular motor protein along microtubules), selectively directing it to dendrites. The KIF5-GRIP1 complex appears to be involved in the transport of GluR2 [26]. GRIP1 has also been found to interact with Ephrin receptors, neuronal RAS guanine nucleotide exchange factor (GRASP1), members of the Liprin- $\alpha$ /syd2 family of proteins, and extracellularmatrix protein FRAS1 [3,5,15,22,32-34]. GRIP1 may therefore play a multifaceted role in assembling and localizing postsynaptic complexes [1]. However, the molecular mechanisms underlying the regulation of AMPA receptor function by GRIP1 remain unclear. To address the assembling and localization of the GRIP1/AMPA receptor complex, it was necessary to identify the GRIP1-interacting proteins. In this study yeast two-hybrid selection was performed, in which the PDZ domains 
1, 2, and 3 of GRIP1 were used as baits. A single interacting protein was discovered, termed p0071/plakophilin-4, an armadillo repeat protein linked to the cytoskeleton.

\section{Materials and Methods}

\section{Plasmid constructs}

A previously described mouse p0071/plakophilin-4 cDNA [12] was cloned into T-vector (Invitrogen, Carlsbad, CA, USA) using by reverse transcriptase polymerase chain reaction (RT-PCR). The amplified fragment was sub-cloned into pLexA and pB42AD (Clontech, Palo Alto, CA, USA). The correct orientation of the cDNA inserts was verified by restriction enzyme analysis, and sequence analysis was used to check that they were in-frame.

Screening of GRIP1-binding proteins by the yeast two-hybrid assay

The Matchmaker LexA two-hybrid system was used for screening according to the manufacturer's manual (Clontech). In brief, a part of the grip1 gene coding 1-335 amino acid length was fused to the DNA-BD region of the pLexA vector, and the plasmid DNA was transformed into yeast strain EGY48 carrying the p8op-lacZ gene. Transformed EGY48 yeast strains containing the GRIP1 bait plasmid were transformed with a mouse brain cDNA library [19] and the cells were grown on synthetic dextrose (SD) plates supplemented with glucose but with no histidine, tryptophan, or uracil (SD/-His/-Trp/-Ura). The selection of positive clones was performed on an SD/-His/-Trp/-Ura/ -Leu plate containing galactose, raffinose, and X-gal. Library plasmids from positive colonies were isolated and rescued using E. coli strain (KC8 strain) on ampicillin-resistant plates. Library inserts analyzed by restriction enzyme digestion. Unique inserts were sequenced, and DNA and protein sequence analysis were performed with the BLAST algorithm at the National Center for Biotechnology Information (NCBI). After isolation of the plasmids encoding the library clones, these plasmids were tested for interactions of the reporter gene in yeast by the retransformation. Activation of the reporter genes in the positive colonies was confirmed in the same experiments.

Cell fractionation, co-immunoprecipitation and Western blot analysis

Cell fractionation was performed using a modified ver- sion of the protocol described by Okada et al. [24]. In brief, one mouse brain was homogenized on ice with a glass homogenizer in $3 \mathrm{ml}$ of homogenization buffer ( $0.32 \mathrm{M}$ sucrose, $4 \mathrm{mM}$ HEPES, pH 7.3) supplemented with protease inhibitors. The homogenate was clarified by centrifugation at $900 \times g$ for $10 \mathrm{~min}$ followed by centrifugation at $1,000 \times$ $g$ for $10 \mathrm{~min}$, producing a pellet (P1) and supernatant (S1). The S1 supernatant was centrifuged again at $12,000 \times g$ for $15 \mathrm{~min}$, and the resulting supernatant (S2) was saved. Protein concentrations were determined using the Bio-Rad DC protein assay kit. For immunoprecipitation of the S2 fraction, the samples were diluted in the same volume of $2 X$ binding buffer (50 mM HEPES, $240 \mathrm{mM} \mathrm{KCl}, 2 \mathrm{mg} / \mathrm{ml}$ BSA, $0.2 \%$ Triton X-100, pH 7.4) and incubated overnight with an anti-GRIP1 antibody (Santa Cruz biotechnology, Santa Cruz, CA, USA) or with control $\mathrm{IgG}$ overnight at $4^{\circ} \mathrm{C}$, followed by precipitation with protein-A Sepharose (Amersham Pharmacia, Piscataway, NJ, USA). The beads were collected by brief centrifugation and washed three times with TBS-T (20 mM Tris-HCl, pH 7.5, 0.15 M NaCl, 0.1\% tween 20). The pellets were eluted and denatured by boiling for $2 \mathrm{~min}$ in Laemmli's loading buffer and then resolved by sodium dodecyl sulphate (SDS)-PAGE. The gel was transferred to a nitrocellulose membrane and incubated with antibodies against the GluR2 [26], and p0071/plakophilin-4 (Abgent, San Diego, CA, USA). Rabbit horseradish-linked secondary antibody (Sigma-Aldrich, St. Louis, MO, USA) was used at a final dilution of 1:2000, and inmmunoreactivities were detected using the ECL Western blotting system.

\section{Glutathione S-transferase (GST) pull-down assays}

Pull-down assays using GST fusion proteins were performed as follows. cDNAs encoding the domains of p0071/ plakophilin-4 were cloned in pET41, and the recombinant GST-p0071/plakophilin-4 fusion proteins were expressed in bacterial strain BL21 GOLD (Stratagene, La Jolla, CA, USA) after induction with $1 \mathrm{mM}$ isopropyl thio- $\beta$-D-galactopyranoside (Fisher Biotech, South Australia, Australia). The fusion proteins were purified using glutathione-agarose beads (Sigma-Aldrich). GST alone or GST fusion proteins were dialyzed for $2 \mathrm{hr}$ in PBS using Slide-A-Lyzer (Pierce, Rockford, IL, USA). Ten $\mu \mathrm{g}$ of each of the GST fusion proteins was then coupled to $50 \mu \mathrm{l}$ of glutathione-agarose beads for each reaction by incubating at room temperature for $1 \mathrm{hr}$, followed by rinsing several times with PBS. The mouse brain S2 fraction was incubated overnight at $4^{\circ} \mathrm{C}$ with the GST 
fusion protein-coupled glutathione beads. The beads were pelleted by centrifugation, washed three times with the extraction buffer ( $1 \%$ Triton X-100 in PBS containing $10 \mu \mathrm{g} / \mathrm{ml}$ each aprotinin, leupeptin, and pepstatin and $1 \mu \mathrm{M}$ phenylmethanesulfonyl fluoride), and once with PBS. The bound proteins were eluted from the glutathione beads with 100 $\mu \mathrm{l}$ of SDS sample buffer. The samples were boiled for $5 \mathrm{~min}$ and then processed for SDS-PAGE and Western blotting with antibody to GRIP1.

\section{Results}

Identification of GRIP1 interacting proteins by
yeast two-hybrid screening

The elucidation of GRIP1 function in the mammalian nervous system has been complicated by the presence of multiple PDZ domains. To address the function of the GRIP1, yeast two-hybrid system was performed, in which the PDZ domains 1, 2, and 3 of GRIP1 were used as baits. Out of the approximately $6 \times 10^{6}$ colonies in a mouse brain
cDNA library screened, 16 positive clones were obtained. These clones were individually isolated, sequenced and subjected to further yeast two-hybrid filter assay to confirm the interactions. Among these, ten clones were identified as p0071/plakophilin-4 and overlapped at the C-terminal region (Fig. 1A). p0071/plakophilin-4 is a member of the armadillo protein family (Fig. 1A) [13,14]. GRIP1 has seven PDZ domains and interact through PDZ4 and PDZ5 with the GluR2 and GluR3 subunits [9,21,30]. To identify the region of GRIP1 required for interaction with p0071/plakophilin-4, a series of deletion mutants of GRIP1 was constructed and the interaction of various GRIP1 constructs with p0071/plakophilin- 4 was analyzed using the yeast two-hybrid system. This experiment indicated that the minimal domain required for binding was critically dependent on the PDZ containing region of the GRIP1 (Fig.1B). PDZ-mediated interactions have generally been reported to occur via recognition of a short motif that usually contains 3-7 critical residues located in the extreme C-terminal domain [27]. Such as most PDZ domain-interacting proteins, the last three amino acids of

(A)

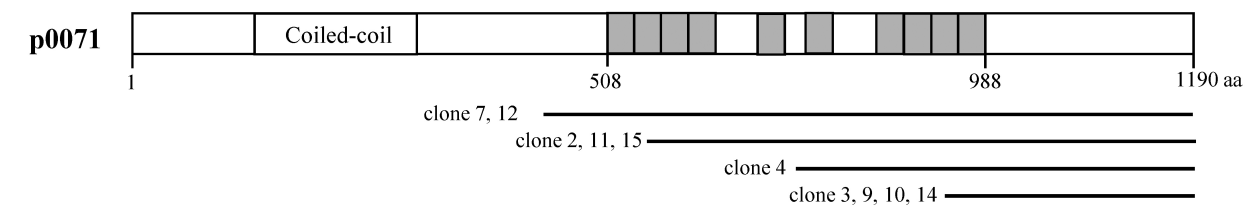

(B)

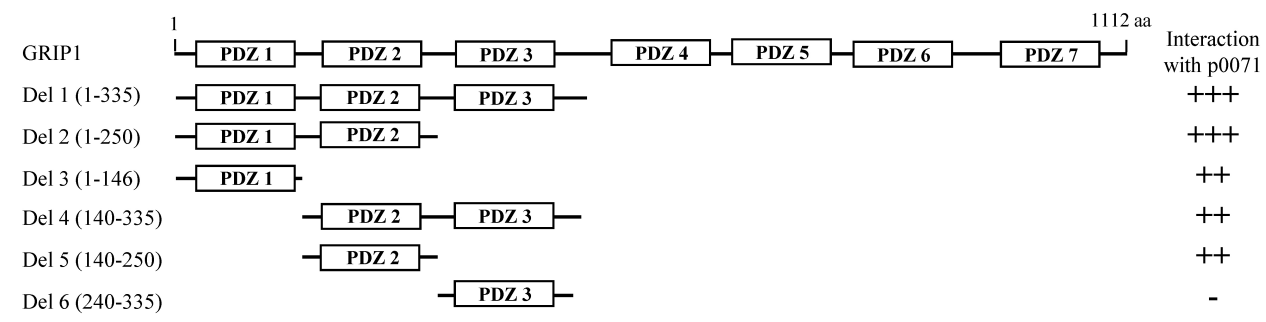

(C)
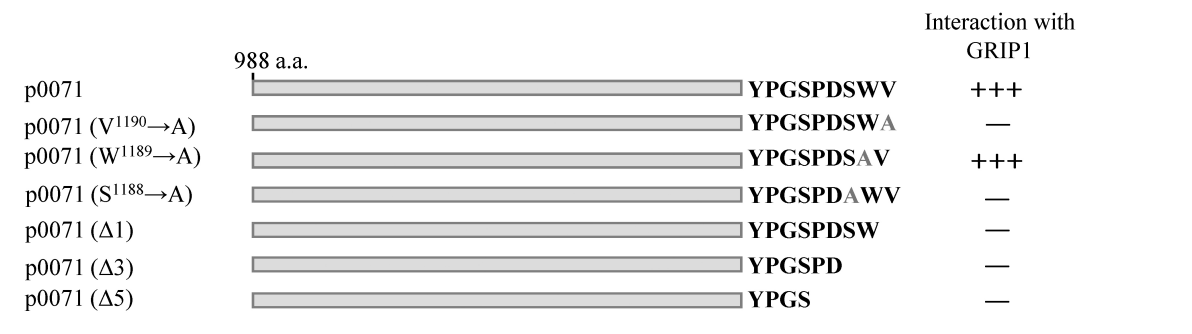

Fig. 1. Identification of the proteins interacting with GRIP1 by yeast two-hybrid screening. (A) Schematic diagram of domain structure of p0071/plakophilin-4. The filled box corresponds to armadillo repeat domain and the open box to the coiled-coil domain. Selected clones were overlapped at the open reading frame (ORF) of p0071/plakophilin 4 . aa, the amino acid residue number. (B) Minimal p0071/plakophilin-4 binding region in GRIP1. PDZ domains are indicated in open box. Truncated GRIP1s were constructed by PCR. Several truncated forms of GRIP1 were tested in the yeast two-hybrid assay for interaction with p0071/plakophilin-4. Amino acid numbers are indicated on the left. +, interaction with p0071/plakophilin-4; -, no interaction with p0071/plakophilin-4. aa, the amino acid residue number. (C) Specific interaction of GRIP1 with the C-terminus of p0071/plakophilin-4. Several point mutant and deletion mutant forms of p0071/plakophilin-4 were tested in the yeast two-hybrid assay for interaction with GRIP1. +++, interaction with GRIP1; -, no interaction with GRIP1. 
p0071/plakophilin-4 contain a functional type I PDZ target motif (S-X-W; S, Ser; X, any amino acid; W, Trp) that mediates protein-protein interaction [12]. For this purpose, a series of C-terminal point mutants and deletion mutants of p0071/plakophilin-4 were constructed (Fig. 1C), and co-transfected into yeast cells with pB42AD-GRIP1. As shown in Fig. 1C, the S-X-W motif-containing p0071/plakophilin-4 can interact with GRIP1. In contrast, the S-X-W deletion mutants and point mutants could not interact with GRIP1. These results indicate that the interaction between GRIP1 and p0071/plakophilin-4 is mediated through a PDZ-domain similar to the previously described interaction between PICK1, and AMPA receptor subtypes [33].

Members of the plakophilin family share a characteristic organization of their arm repeat domain. This family is composed of plakophilin-1, -2, -3, and p0071/ plakophilin-4 [13]. When the C-terminal regions of plakophilins-1, $-2,-3$ and p0071/plakophilin-4 were tested for GRIP1-binding by yeast two-hybrid assays, there was no detectable binding between GRIP1 and the tail regions of plakophilins-1, -2 , and -3 (Fig. 2). These data indicate that the interaction of GRIP1 with p0071/plakophilin-4 is specific to the C-terminal region of p0071/plakophilin-4.

GRIP1 is associated with p0071/plakophilin-4 in vitro and in vivo

To confirm the GRIP1-p0071/plakophilin-4 interaction, the direct interaction between GRIP1 and p0071/plakophilin-4 was assayed using the GST pull-down assay. Recombinant GST-p0071/plakophilin-4 or GST-p0071/
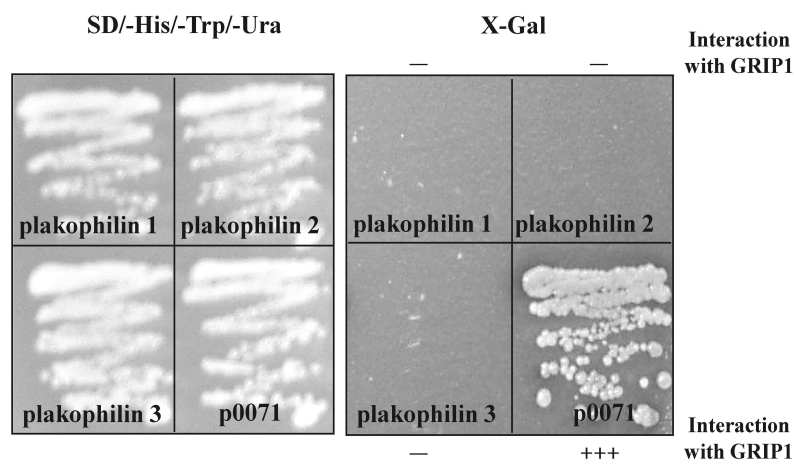

Fig. 2. Interaction between plakophilins and GRIP1. The C-terminal regions of each plakophilin protein were fused to the pLexA DNA binding domain. GRIP1 specifically interacted with p0071/plakophilin-4 but not with plakophilin-1, -2 , or -3 . +++, interaction with GRIP1; -, no interaction with GRIP1.
(A)

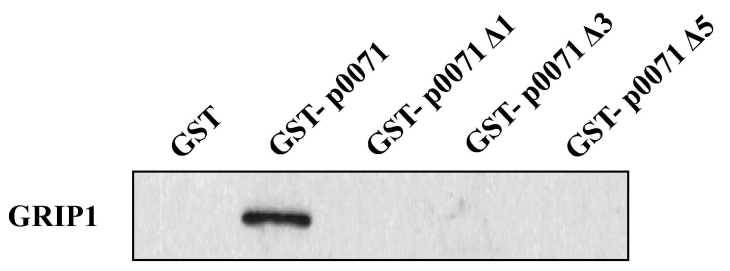

(B)

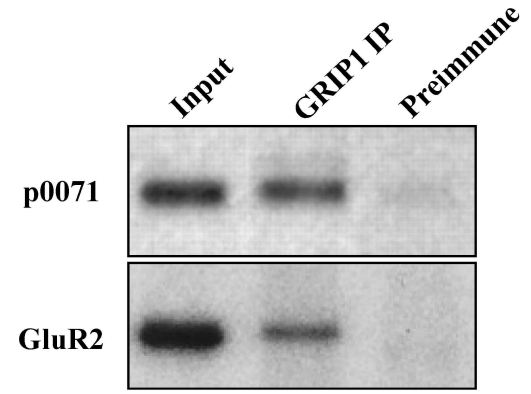

Fig. 3. Association of p0071/plakophilin-4 with GRIP1 in the GST pull-down assay and co-immunoprecipitation. (A) Proteins in the mouse brain lysate were allowed to bind to GST alone or to GST-p0071/plakophilin-4 fusion proteins containing the several truncated tail domains of p0071/plakophilin-4. The elution fractions were resolved by SDS-PAGE, and Western blotting was performed using an antibody to GRIP1. (B) Mouse brain lysates were immunoprecipitated with an anti-GRIP1 antibody or preimmune serum, and the precipitates were immunoblotted with anti-GluR antibody or anti-p0071/plakophilin-4 antibody. Input: $10 \%$ of the mouse brain lysates used for each co-immunoprecipitation assay.

plakophilin-4 C-terminal deletion fusion proteins were expressed in E. coli and purified by affinity chromatography. Immunoblot analysis showed that GRIP1 interacted with p0071/plakophilin-4, but not with GST alone, consistent with the yeast two-hybrid results. Deletion mutation of the last amino acid residue of p0071/plakophilin-4 interrupted interaction with GRIP1 (Fig. 3A), indicating that GRIP1 and p0071/plakophilin-4 binding is dependent on the C-terminus of p0071/plakophilin-4. This result further indicates that the GIRP1 directly interacts with p0071/plakophilin-4 through a PDZ-mediated interaction.

In order to determine whether the interaction between GRIP1 and p0071/plakophilin-4 occurs in vivo immunoprecipitation analyses were performed. Lysates from mouse brain were incubated with a GRIP1 antibody. Protein G-agarose beads selectively precipitated the immuno-complexes, which were subsequently separated by SDS-PAGE and immunoblotted with anti-p0071/plakophilin-4 antibody and anti-GluR2 antibody. An antibody to GRIP1 was coim- 
munoprecipitated p0071/plakophilin-4 and GluR2 (Fig. 3B). This result is consistent with the yeast two-hybrid and pull-down results. Taken together, these results show that GRIP1 and p0071/plakophilin-4 specifically interact each other in vivo.

\section{Discussion}

Receptor clustering appears to be mediated by binding of the C-terminal tail of certain glutamate-receptor subunits to a family of proteins that express the PDZ modular protein interaction domain [27]. These PDZ-containing proteins presumably form a scaffold or bridge between receptor and cytoskeletal proteins located near the postsynaptic membrane [28]. In this report, using the two-hybrid system, p0071/plakophilin-4 was identified as a new interactor for GRIP1. The interaction of GRIP1 and with p0071/plakophilin-4 was confirmed by two independent methods, i.e binding to GST fusion proteins, and immunoprecipitation from brain lysate.

The armadillo repeat is a repeated motif of about $40 \mathrm{ami}-$ no acids originally identified in the Drosophila segment polarity gene $[2,11,13,14,23]$. In neurons, the p0071/plakophilin-4 armadillo repeats 2-10 are necessary and sufficient to mediate the interaction with the hydrophilic loop of presenilin 1, a protein involved in neurodegenerative disorders. It is also reported that the C-terminus of p0071/plakophilin-4 terminates with a PDZ domain-binding motif and interacts with the PDZ motif-containing protein PAPIN and with the LAP protein Erbin [6,12,8,18,20,30,31].

This study showed that GRIP1 interacts with p0071/plakophilin-4 an armadillo repeat-containing protein. It draws our attention that the armadillo repeat-containing proteins bind actin or intermediate filaments [6,12], because our findings provide with a clue to how AMPA receptors are linkined to cytoskeletons. Since GRIP1 interacts with p0071/plakophilin-4, it is tempting to assume a cytoskeleton-p0071/ plakophilin-4 -GRIP1-AMPA receptor link.

Many junctional proteins, such as PSD-95, SAP97, synaptic scaffolding molecule, membrane associated guanylate kinase-1, ZO-1, and channel-interacting PDZ domain protein, have more than one PDZ domains $[4,17,27,28]$. Multiple copies of PDZ domains in the same protein help scaffold an array of receptors, enzymes, and adaptors, thus creating a functional unit. GRIP1 may also interact with various molecules besides AMPA receptor and p0071/plakophilin-4 via the PDZ domains. The ability of p0071/plakophilin- 4 to in- teract with GRIP1 may affect synaptic functions.

\section{Acknowledgement}

This work was supported by an Inje University Research Grant for 2008.

\section{References}

1. Bladt, F., A. Tafuri, S. Gelkop, L. Langille, and T. Pawson. 2002. Epidermolysis bullosa and embryonic lethality in mice lacking the multi-PDZ domain protein GRIP1. Proc. Natl. Acad Sci. USA 99, 6816-6821.

2. Bonné, S., B. Gilbert. M. Hatzfeld, X. Chen, K. J. Green, and F. van Roy. 2003. Defining desmosomal plakophilin-3 interactions. J. Cell Biol. 161, 403-416.

3. Brenman, J. E., D. S. Chao, S. H. Gee, A. W. McGee, S. E. Craven, D. R. Santillano, Z. Wu, F. Huang, H. Xia, M. F. Peters, S. C. Froehner, and D. S. Bredt. 1996. Interaction of nitric oxide synthase with the postsynaptic density protein PSD-95 and alpha1-syntrophin mediated by PDZ domains. Cell 84, 757-767.

4. Brenman, J. E., J. R. Topinka, E. C. Cooper, A. W. McGee, J. Rosen, T. Milroy, H. J. Ralston, and D. S. Bredt. 1998. Localization of postsynaptic density-93 to dendritic microtubulesand interaction with microtubule-associated protein 1A. J. Neurosci. 18, 8805-8813.

5. Bruckner, K., J. Pablo Labrador, P. Scheiffele, A. Herb, P. H. Seeburg, and R. Klein. 1999. EphrinB ligands recruit GRIP family PDZ adaptor proteins into raft membrane microdomains. Neuron 22, 511-524.

6. Calkins, C. C., B. L. Hoepner, C. M. Law, M. R. Novak, S. V. Setzer, M. Hatzfeld, and A. P. Kowalczyk. 2003. The Armadillo family protein p0071 is a VE-cadherin- and desmoplakin-binding protein. J. Biol. Chem 278, 1774-1783.

7. Chen, L., S. Bao, X. Qiao, and R. F. Thompson. 1999. Impaired cerebellar synapse maturation in waggler, a mutant mouse with a disrupted neuronal calcium channel gamma subunit. Proc. Natl. Acad Sci. USA 96, 12132-12137.

8. Deguchi, M., T. Iizuka, Y. Hata, W. Nishimura, K. Hirao, I. Yao, H. Kawabe, and Y. Takai. 2000. PAPIN. A novel multiple PSD-95/Dlg-A/ZO-1 protein interacting with neural plakophilin-related armadillo repeat protein/delta-catenin and p0071. J. Biol. Chem 275, 29875-29880.

9. Dong, H., R. J. O'Brien, E. T. Fung, A. A. Lanahan, P. F. Worley, and R. L. Huganir. 1997. GRIP: a synaptic PDZ domain-containing protein that interacts with AMPA receptors. Nature 386, 279-284.

10. Hashimoto, K., M. Fukaya, X. Qiao, K. Sakimura, M. Watanabe, and M. Kano. 1999. Impairment of AMPA receptor function in cerebellar granule cells of ataxic mutant mouse stargazer. J. Neurosci. 19, 6027-6036.

11. Hatzfeld, M., C. Haffner, K. Schulze, and U. Vinzens. 2000. The function of plakophilin 1 in desmosome assembly and 
actin filament organization. J. Cell Biol. 149, 209-222.

12. Hatzfeld, M. and C. Nachtsheim. 1996. Cloning and characterization of a new armadillo family member, p0071, associated with the junctional plaque: evidence for a subfamily of closely related proteins. J. Cell Sci. 109, 2767-2778.

13. Hatzfeld, M. 2007. Plakophilins: Multifunctional proteins or just regulators of desmosomal adhesion? Biochim Biophys. Acta. 1773, 69-77.

14. Hatzfeld, M. 1999. The armadillo family of structural proteins. Int. Rev. Cytol. 186, 179-224.

15. Hillier, B. J., K. S. Christopherson, K. E. Prehoda, D. S. Bredt, and W. A. Lim. 1999. Unexpected modes of PDZ domain scaffolding revealed by structure of nNOS-syntrophin complex. Science 284, 812-815.

16. Hollmann, M. and S. Heinemann. 1994. Cloned glutamate receptors. Annu. Rev. Neurosci. 17, 31-108.

17. Ikeda, A., Q. Y. Zheng, A. R. Zuberi, K. R. Johnson, J. K. Naggert , and P. M. Nishina. 2002. Microtubule-associated protein $1 \mathrm{~A}$ is a modifier of tubby hearing (moth1). Nat. Genet. 30, 401-405.

18. Jaulin-Bastard, F., J. P. Arsanto, A. Le Bivic, C. Navarro, F. Vuly, H. Saito, S. Marchetto, M. Hatzfeld, M. J. Santoni, D. Birnbaum, and J. P. Borg. 2002. Interaction between Erbin and a Catenin-related protein in epithelial cells. J. Biol. Chem 277, 2869-2875.

19. Kim, S. J., C. H. Lee, H. Y. Park, S. S.Yea, W. H. Jang, S. K. Lee, Y. H. Park, O. S. Cha, I. S. Moon, and D. H. Seog. 2007. JSAP1 interacts with kinesin light chain 1 through conserved binding segments. J. Life Sci. 17, 889-895.

20. Lampugnani, M. G., M. Corada, L. Caveda, F. Breviario, O. Ayalon, B. Geiger, and E. Dejana. 1995. The molecular organization of endothelial cell to cell junctions: differential association of plakoglobin, beta-catenin, and alpha-catenin with vascular endothelial cadherin (VE-cadherin). J. Cell Biol. 129, 203-217.

21. Leonard, A. S., M. A. Davare, M. C. Horne, C. C. Garner, and J. W. Hell. 1998. SAP97 is associated with the alpha-amino-3-hydroxy-5-methylisoxazole-4-propionic acid receptor GluR1 subunit. J. Biol. Chem 273, 19518-19524.

22. Lin, D., G. D. Gish, Z. Songyang, and T. Pawson. 1999. The carboxyl terminus of $\mathrm{B}$ class ephrins constitutes a PDZ domain binding motif. J. Biol. Chem. 274, 3726-3733.

23. Mertens, C., C. Kuhn, and W. W. Franke. 1996. Plakophilins
$2 \mathrm{a}$ and $2 \mathrm{~b}$ : constitutive proteins of dual location in the karyoplasm and the desmosomal plaque. J. Cell Biol. 135, 1009-1025.

24. Okada, Y., H. Yamazaki, Y. Sekine-Aizawa, and N. Hirokawa. 1995. The neuron-specific kinesin superfamily protein KIF1A is a unique monomeric motor for anterograde axonal transport of synaptic vesicle precursors. Cell 81, 769-780.

25. Osten, P., L. Khatri, J. L. Perez, G. Kohr, G. Giese, C. Daly, T. W. Schulz, A. Wensky, L. M. Lee, and E. B. Ziff. 2000. Mutagenesis reveals a role for ABP/GRIP binding to GluR2 in synaptic surface accumulation of the AMPA receptor. Neuron 27, 313-325.

26. Setou, M., D. H. Seog, Y. Tanaka, Y. Kanai, Y. Takei, M. Kawagishi, and N. Hirokawa. 2002. Glutamate-receptor-interacting protein GRIP1 directly steers kinesin to dendrites. Nature 417, 83-87.

27. Sheng, M. and C. Sala. 2001. PDZ domains and the organization of supramolecular complexes. Annu. Rev. Neurosci. 24, 1-29.

28. Sheng, M. 2001. Molecular organization of the postsynaptic specialization. Proc. Natl. Acad Sci. USA 98, 7058-7061.

29. Song, I. and R. L. Huganir. 2002. Regulation of AMPA receptors during synaptic plasticity. Trends Neurosci. 25, 578-588.

30. Srivastava, S. and E. B. Ziff. 1999. ABP: a novel AMPA receptor binding protein. Ann. NY Acad Sci. 86, 561-564.

31. Stahl, B., A. Diehlmann, and T. C. Sudhof. 1999. Direct interaction of Alzheimer's disease-related presenilin 1 with armadillo protein p0071. J. Biol. Chem 274, 9141-9148.

32. Torres, R., B. L. Firestein, H. Dong, J. Staudinger, E. N. Olson, R. L. Huganir, D. S. Bredt, N. W. Gale, and G. D. Yancopoulos. 1998. PDZ proteins bind, cluster, and synaptically colocalize with Eph receptors and their ephrin ligands. Neuron 21, 1453-1463.

33. Xia, J., X. Zhang, J. Staudinger, and R. L. Huganir. 1999. Clustering of AMPA receptors by the synaptic PDZ domain-containing protein PICK1. Neuron 22, 179-187.

34. Ye, B., D. Liao, X. Zhang, P. Zhang, H. Dong, and R. L. Huganir. 2000. GRASP-1: a neuronal RasGEF associated with the AMPA receptor/GRIP complex. Neuron 26, 603-617. 

초록 : Glutamate receptor-interacting protein 1 단백질과 armadillo family 단백질 p0071/ plakophilin-4와의 결합
문일수 ${ }^{*}$ 석대현*
(인제대학교 의과대학생화학교실, ${ }^{1}$ 동국대학교 의과대학 해부학교실)

a-amino-3-hydroxy-5-methyl-4-isoxazole propionate (AMPA) 수용체는 중추신경계에 널리 발현하며, 연접부위 에서 글루타메이트에 의한 흥분성 신경전달의 역할을 행한다. 이러한 수용체의 조절은 학습과 기억에 관여한다. 본 연구에서는 AMPA receptor subunit glutamate receptor-interacting protein 1 (GRIP1)과 결합하는 단백질로 armadillo family인 p0071/plakophilin-4을 분리하였다. GRIP1 단백질은 p0071/plakophilin-4 단백질의 C-말단과 결합하며, armadillo family 단백질 중 p0071/plakophilin-4 과만 결합한다. 효모 two-hybrid assay에서 GRIP1의 Postsynaptic density-95/Discs large/Zona occludens-1 (PDZ) 영역이 p0071/plakophilin-4 단백질과의 결합에 관 여하며, p0071/plakophilin-4 단백질의 C-말단 아미노산인 "S-X-V" 배열이 결합에 필수적이었다. 이러한 결합은 뇌 균질액에서 Glutathione Stransferase (GST) pull-down assay와 공면역침강법으로 확인하였다. 이러한 결과들은 $\mathrm{AMPA}$ 수용체가 연접후막에 안정적으로 위치하는 새로운 역할을 시사한다. 